\title{
Effect of Seed Sowing and Scarification Methods on Germination and Growth of Chironji (Buchnania lanzan Spreng)
}

\author{
Kamal Narayan $^{1 *}$, Deo Shankar ${ }^{2}$, Kedar Nath Yadaw ${ }^{1}$ and Narayan Sahu ${ }^{1}$ \\ ${ }^{1}$ Krishi Vigyan Kendra, Dantewada, IGKV, Raipur (C.G.), India \\ ${ }^{2}$ SGCARS, Jagdalpur, IGKV, Raipur (C.G.), India \\ *Corresponding author
}

\section{A B S T R A C T}

Chironji, a multipurpose tree provides food, fuel, fodder, timber and medicine to the local community. The species is well known for its kernel which has high nutritive value with rich source of fat, protein and mineral. It is free for collection, as a result of which the local inhabitants, traders and greedy merchants destroy the branches/whole trees during

\section{Keywords}

Chironji, germination, Scarification, Sowing method, propagation

Article Info

Accepted:

15 May 2018

Available Online:

10 June 2018 collection of its fruits without bothering about new plantations. This has led to the destruction of Chironji plants in the forests. Due to poor rate of seed germination, method of sowing is an important aspect of nursery for Buchnania lanzan which needs to be standardized. Keeping these points in view the present study was done at Krishi Vigyan Kendra, Dantewada, I.G.K.V., Raipur (C.G.) during the year 2014-15. Experiment was conducted under factorial randomized design block design under which different seed rupturing method (Seed sown normally, Soaking of seeds in water overnight, Mechanical rupturing of seed coat by hammer before sowing of seeds, Hot water treatment at $50{ }^{0} \mathrm{C}$ for 30 minutes, Seed treatment by $5 \% \mathrm{H}_{2} \mathrm{SO}_{4}$ for 10 minutes and Soaking of seeds in cow dung overnight) and seed sowing method (Direct sowing in soil and seed sown in polythene bag). Seed germination of $75 \%$ within 20 days could be achieved with satisfactory seedling growth i.e. plant height and survival percentage by mechanically rupturing the stony endocarp with hammer before sowing of seed. Seed sown directly in soil recorded significant effect for germination percentage, days to germination, plant height and survival percentage of Chironji saplings.

\section{Introduction}

Dantewada District, a part of the Bastar zone, is one of the most backward districts of Chhattisgarh. Most of the people in this district belong to tribal communities. Their major sources of income are farming and collection and selling of minor forest-based products. Major crops are rice and finger millet, but due to the lack of irrigation facilities, agriculture depends entirely on the monsoon leading to poor productivity of crops. Collection and selling of minor forest based produce; especially Chironji (one of the important multipurpose forest species) brings income to the local inhabitants. The tribal's of Dantewada district collected about 100 qt. Of Chironji seeds annually (DFO, Dantewada, 2012-13). Chironji (Buchnania lanzan Spreng syn. B. latifolia Roxb), also known as Char, 
Piyal or Achar belongs to the family Anacardiaceae. It is a subtropical, underutilized/ underexploited nut fruit and is considered to be native to India. Chironji trees are common in our forests mostly in eroded ravine lands. It avoids water logged areas but occurs locally in clay and red soil. Identified by, dark grey crocodile bark with red blaze. A good species for afforesting bare hill slopes. It has coppicing capacity and produce root suckers sparingly. Pyramidal panicles of greenish white flower appear in JanuaryMarch. Fruits ripen from April-May and remain on the tree for quite a long time. Fruits are drupe, globose (0.8-1.3 cm dia.), black when ripe, stones hard, 2-valved, seed biconvex, oily, the fruits and kernels are edible. Fruits can be collected from the tree in April-May and depulped to get the cleaned seed. The viability period is one year when stored in sealed tins. About 3000-5000 seeds obtained in one $\mathrm{Kg}$ weight. This multipurpose tree provides food, fuel, fodder, timber and medicine to the local community. It is a popular and edible nut fruit, eaten raw or roasted and also used in making dessert. During summer when green fodder becomes unavailable, local inhabitants use its leaf as green fodder for their animals, especially buffalo, goat and sheep. Its dried wood is utilized as a fuel. At present the plant is grouped as an underexploited and nonnationalized minor forest produce. It is free for collection, as a result of which the local inhabitants, traders and greedy merchants destroy the branches/whole trees during collection of its fruits without bothering about new plantations. This has led to the destruction of Chironji plants in the forests. There is an urgent need to develop a technology for easy multiplication and regeneration of Chironji, and to popularize its importance among local inhabitants/tribal's. The tree is propagated from seeds which are contained inside a hard shell. Before sowing, challenging task is to crack the shell carefully, as the fruit inside it is often extremely soft and tender. It grows moderately fast and tolerates drought too! Though in earlier times, the forests were full of them, now they are facing mass destruction.

\section{Materials and Methods}

An experiment was carried out at Krishi Vigyan Kendra, Dantewada (South Bastar) IGKV, Raipur, Chhattisgarh during 2014-15. The Soil of the experimental site is silty-loam and $\mathrm{P}^{\mathrm{H}}$ of the soil ranging from 5.5 to 6.1. Four raised beds of $10 \mathrm{~m} \times 1 \mathrm{~m} \times 0.15 \mathrm{~m}$ size were prepared and well decomposed FMY is properly mixed into top soil of the bed @ 50 $\mathrm{Kg} / \mathrm{bed}$ and $1.0 \mathrm{~kg}$ of NPK/bed. Each raised bed consists of six plots for accommodation of six treatments and in each plot 100 seeds of the treatments were used and another method of seed sowing, polythene bags were filled with soil, sand and FYM with the ratio of $2: 1: 1$. Six treatments were allocated in polythene bags in four replications; each treatment consists of 100 polythene bags. The seeds were sown $2-3 \mathrm{~cm}$ deep in the nursery bed during the month of September. The experiment was laid in Factorial Randomized Block Design with two factors and each factor consists of six treatments and four replications. The treatment details are given below:-

\section{Seed sowing methods in nursery}

$\mathrm{S}_{1}$ - Direct sowing of seeds in nursery bed $\mathrm{S}_{2}$ - Seed sown in polythene bags

The biometric observations were recorded on germination percentage, days taken for germination, plant height $(\mathrm{cm})$ after two month, four month, six month and one year of germination of seed and survival percentage after two month, four month, six month and one year of germination of seed. The data collected from different characters were 
processed and were analyzed by the method of analysis of variance given by Gomez and Gomez (1984).

\section{Results and Discussion}

\section{Germination percentage and days taken for germination}

The table-2 showed the significant differences for germination percentage and days taken for germination in different seed coat rupturing method and nursery sowing method. The treatment mechanically rupturing of stony seed coat with hammer before sowing of seed recorded highest percentage of germination $75.0 \%$ and 61.25 respectively in seed sown direct in soil and polythene. Seed sown direct in nursery found better and significant percentage of germination as compare to seed sown in polythene bags. However, minimum percentage of germination was recorded in control (seed sown without treatment) under both the condition. In this experiment, we found that seed germination percentage were affected by different rupturing method and nursery sowing method and observed that seed sown directly in nursery with mechanically rupturing of seed coat with hammer gave higher germination. The direct sowing of seeds in nursery or soil is applied only where seeded plant are needed but for commercial propagation, seed sown in polythene were used as Chironji is propagated commercially by soft wood grafting. The treatment seed coat rupturing of seed coat by hammer takes minimum days 20.0 days and 24.50 days under seed sown direct in nursery and polythene bags, respectively. However, the control treatment recorded the maximum days for germination 29.25 days and 31.25 days under direct and polythene bags sowing methods respectively. The interaction of seed rupturing methods and nursery sowing methods showed the non-significant differences. Sukla and Solanki (2000) also recorded the seed germination of $83 \%$ within 18 days with satisfactory seedling growth by mechanically damaging the seed coat with hammer before sowing of seed. Centre of Forest Research and Human Resource Development, Chhindwara (Annual Report, 2005-06) also reported that the seed of Buchnania Lanzan treated mechanically by hammer gave better germination and seedling growth. Mechanical scarification allows water and air to enter into the seed and stimulate germination. The enhanced germination observed in the mechanical treatment could be attributed to water uptake by the quiescent dry seed, which ended up with the elongation of the embryonic axis.

\section{Seed rupturing methods}

\begin{tabular}{|l|l|l|}
\hline $\mathrm{T}_{1}$ & $:$ & Seed sown normally \\
\hline $\mathrm{T}_{2}$ & $:$ & Soaking of seeds in water overnight \\
\hline $\mathrm{T}_{3}$ & $:$ & Mechanical rupturing of seed coat by hammer before sowing of seeds \\
\hline $\mathrm{T}_{4}$ & $:$ & Hot water treatment at $50{ }^{0} \mathrm{C}$ for 30 minutes \\
\hline $\mathrm{T}_{5}$ & $:$ & Seed immersed in $5 \%$ concentrated $\mathrm{H}_{2} \mathrm{SO}_{4}$ for 10 minutes \\
\hline $\mathrm{T}_{6}$ & $:$ & Seed immersed in cow dung for overnight \\
\hline
\end{tabular}

Table.1 Nutritional value and Physio-Chemical Properties of Chironji

\begin{tabular}{|l|l|l|l|l|l|l|l|l|l|l|}
\hline $\begin{array}{l}\text { Physio- } \\
\text { chemical } \\
\text { properties }\end{array}$ & $\begin{array}{l}\text { Fat } \\
(\mathbf{m g})\end{array}$ & $\begin{array}{l}\text { Protein } \\
(\mathbf{\%})\end{array}$ & $\begin{array}{l}\text { Starch } \\
(\mathbf{\%})\end{array}$ & $\begin{array}{l}\text { Calcium } \\
(\mathbf{m g})\end{array}$ & $\begin{array}{l}\text { Phospho } \\
\text { rus } \mathbf{( m g )}\end{array}$ & $\begin{array}{l}\text { Iron } \\
(\mathbf{m g})\end{array}$ & $\begin{array}{l}\text { Thiami } \\
\text { ne } \\
(\mathbf{m g})\end{array}$ & $\begin{array}{l}\text { vitamin } \\
\text { C (mg) }\end{array}$ & $\begin{array}{l}\text { Niacin } \\
(\mathbf{m g})\end{array}$ & $\begin{array}{l}\text { Oil } \\
(\mathbf{\%})\end{array}$ \\
\cline { 2 - 10 } & 59.0 & $63-72$ & 12.1 & 279 & 528 & 8.5 & 0.69 & 5.0 & 1.5 & $34-47$ \\
\hline
\end{tabular}

(Gopalan et al., 1982) 
Table.2 Influence of scarification on seed germination (\%) and days taken for germination of Chironji

\begin{tabular}{|c|c|c|c|c|c|}
\hline \multirow{2}{*}{$\mathbf{S . N}$} & \multirow[t]{2}{*}{ Treatments } & \multicolumn{2}{|c|}{ Germination (\%) } & \multicolumn{2}{|c|}{ Days taken to germination } \\
\hline & & Direct sown & Polythene sown & Direct sown & Polythene sown \\
\hline 1 & $\begin{array}{l}\text { Control (Without } \\
\text { Treatment) }\end{array}$ & 39.25 & 28.27 & 29.25 & 31.25 \\
\hline 2 & $\begin{array}{l}\text { Soaking of seeds in } \\
\text { water overnight }\end{array}$ & 42.25 & 37.25 & 28.50 & 29.50 \\
\hline 3 & $\begin{array}{l}\text { Scarification by } \\
\text { Hot } \\
\text { treatment }\end{array}$ & 47.50 & 39.00 & 26.25 & 29.00 \\
\hline $\mathrm{T4}$ & $\begin{array}{l}\text { Scarification by } \\
\mathrm{H}_{2} \mathrm{SO}_{4}\end{array}$ & 61.50 & 50.75 & 25.00 & 27.75 \\
\hline T5 & $\begin{array}{l}\text { Scarification by } \\
\text { Hammer }\end{array}$ & 75.00 & 61.25 & 20.00 & 24.50 \\
\hline 66 & $\begin{array}{l}\text { Seed immersed in } \\
\text { cow dung for } \\
\text { overnight }\end{array}$ & 57.25 & 47.75 & 25.75 & 27.75 \\
\hline
\end{tabular}

ANOVA table for seed germination (\%) and days taken for germination

\begin{tabular}{|c|c|c|c|c|}
\hline \multirow{2}{*}{ Factors } & \multicolumn{2}{|c|}{ Seed germination } & \multicolumn{2}{c|}{ Days taken for germination } \\
\hline Factor(A) & C.D. & SE(m) & C.D. & SE(m) \\
\hline Factor(B) & 1.383 & 0.478 & 1.071 & 0.371 \\
\hline Factor(A X B) & 2.395 & 0.829 & 1.855 & 0.642 \\
\hline
\end{tabular}

Table.3 Influence of scarification on survival percentage (\%) of Chironji saplings

\begin{tabular}{|c|c|c|c|c|c|c|c|c|c|}
\hline $\begin{array}{l}\mathbf{S} \text {. } \\
\mathbf{N}\end{array}$ & Treatments & $\begin{array}{r}\text { Two } \\
\text { germil }\end{array}$ & $\begin{array}{l}\text { nth after } \\
\text { on of seed }\end{array}$ & $\begin{array}{l}\text { Four } \\
\text { germin }\end{array}$ & $\begin{array}{l}\text { nth after } \\
\text { on of seed }\end{array}$ & $\begin{array}{r}\text { Six n } \\
\text { germin }\end{array}$ & $\begin{array}{l}\text { nth after } \\
\text { ion of seed }\end{array}$ & $\begin{array}{r}\text { One } \\
\text { germin }\end{array}$ & $\begin{array}{l}\text { ar after } \\
\text { on of seed }\end{array}$ \\
\hline & & $\begin{array}{l}\text { Direct } \\
\text { sown }\end{array}$ & $\begin{array}{l}\text { Polythene } \\
\text { sown }\end{array}$ & $\begin{array}{l}\text { Direct } \\
\text { sown }\end{array}$ & $\begin{array}{l}\text { Polythene } \\
\text { sown }\end{array}$ & $\begin{array}{l}\text { Direct } \\
\text { sown }\end{array}$ & $\begin{array}{l}\text { Polythene } \\
\text { sown }\end{array}$ & $\begin{array}{l}\text { Direct } \\
\text { sown }\end{array}$ & $\begin{array}{l}\text { Polythene } \\
\text { sown }\end{array}$ \\
\hline$\overline{1}$ & $\begin{array}{l}\text { Control (Without } \\
\text { Treatment) }\end{array}$ & 80.00 & 79.50 & 71.00 & 66.25 & 55.75 & 49.00 & 44.75 & 39.50 \\
\hline 2 & $\begin{array}{l}\text { Soaking of seeds } \\
\text { in } \\
\begin{array}{l}\text { overnight } \\
\text { water }\end{array}\end{array}$ & 80.75 & 80.25 & 71.25 & 66.50 & 55.75 & 50.00 & 47.50 & 41.00 \\
\hline 3 & $\begin{array}{l}\text { Scarification by } \\
\text { Hot water } \\
\text { treatment }\end{array}$ & 82.00 & 84.50 & 73.25 & 68.75 & 59.25 & 52.50 & 51.00 & 42.00 \\
\hline $\begin{array}{l}T \\
4\end{array}$ & $\begin{array}{l}\text { Scarification by } \\
\mathrm{H}_{2} \mathrm{SO}_{4}\end{array}$ & 90.50 & 87.75 & 81.75 & 75.50 & 69.00 & 59.25 & 55.25 & 50.00 \\
\hline $\begin{array}{l}\mathbf{T} \\
5 \\
\end{array}$ & $\begin{array}{l}\text { Scarification by } \\
\text { Hammer }\end{array}$ & 91.75 & 90.50 & 85.00 & 80.75 & 72.75 & 66.50 & 67.00 & 58.75 \\
\hline 66 & $\begin{array}{l}\text { Seed immersed } \\
\text { in cow dung for } \\
\text { overnight }\end{array}$ & 90.75 & 87.50 & 81.25 & 75.50 & 67.75 & 56.75 & 53.50 & 45.50 \\
\hline
\end{tabular}


ANOVA table for survival percentage (\%)

\begin{tabular}{|c|c|c|c|c|c|c|c|c|}
\hline \multirow{2}{*}{ Factors } & \multicolumn{2}{|c|}{ Two Month } & \multicolumn{2}{c|}{ Four Month } & \multicolumn{2}{c|}{ Six Month } & \multicolumn{2}{c|}{ One Year } \\
\hline & C.D. & SE(m) & C.D. & SE(m) & C.D. & SE(m) & C.D. & SE(m) \\
\hline Factor(A) & N/A & 0.55 & 1.23 & 0.46 & 1.52 & 0.52 & 1.34 & 0.46 \\
\hline Factor(B) & 2.79 & 0.96 & 2.33 & 0.80 & 2.64 & 0.91 & 2.33 & 0.80 \\
\hline Factor(A X B) & N/A & 1.36 & N/A & 1.14 & N/A & 1.29 & N/A & 1.14 \\
\hline
\end{tabular}

Table.4 Influence of scarification on plant height $(\mathrm{cm})$ of Chironji saplings

\begin{tabular}{|c|c|c|c|c|c|c|c|c|c|}
\hline \multirow[t]{2}{*}{$\begin{array}{l}\mathbf{S} . \\
\mathbf{N}\end{array}$} & \multirow[t]{2}{*}{ Treatments } & \multicolumn{2}{|c|}{$\begin{array}{l}\text { Two month after } \\
\text { germination of seed }\end{array}$} & \multicolumn{2}{|c|}{$\begin{array}{l}\text { Four month after } \\
\text { germination of seed }\end{array}$} & \multicolumn{2}{|c|}{$\begin{array}{l}\text { Six month after } \\
\text { germination of seed }\end{array}$} & \multicolumn{2}{|c|}{$\begin{array}{l}\text { One year after } \\
\text { germination of seed }\end{array}$} \\
\hline & & $\begin{array}{l}\text { Direct } \\
\text { sown }\end{array}$ & $\begin{array}{l}\text { Polythene } \\
\text { sown }\end{array}$ & $\begin{array}{l}\text { Direct } \\
\text { sown }\end{array}$ & $\begin{array}{l}\text { Polythene } \\
\text { sown }\end{array}$ & $\begin{array}{l}\text { Direct } \\
\text { sown }\end{array}$ & $\begin{array}{l}\text { Polythene } \\
\text { sown }\end{array}$ & $\begin{array}{l}\text { Direct } \\
\text { sown }\end{array}$ & $\begin{array}{l}\text { Polythene } \\
\text { sown }\end{array}$ \\
\hline 1 & $\begin{array}{l}\text { Control (Without } \\
\text { Treatment) }\end{array}$ & 3.30 & 2.19 & 5.21 & 4.02 & 9.39 & 7.76 & 19.99 & 16.55 \\
\hline 2 & $\begin{array}{l}\text { Soaking of seeds in } \\
\text { water overnight }\end{array}$ & 3.32 & 2.81 & 6.93 & 4.65 & 9.48 & 8.02 & 21.36 & 17.03 \\
\hline 3 & $\begin{array}{l}\text { Scarification by Hot } \\
\text { water treatment }\end{array}$ & 3.40 & 2.99 & 6.99 & 5.77 & 11.56 & 8.99 & 24.11 & 20.56 \\
\hline $\begin{array}{l}T \\
4\end{array}$ & $\begin{array}{l}\text { Scarification by } \\
\mathrm{H}_{2} \mathrm{SO}_{4}\end{array}$ & 3.75 & 3.12 & 7.78 & 6.12 & 13.11 & 10.16 & 26.71 & 22.11 \\
\hline $\begin{array}{l}\mathbf{T} \\
5\end{array}$ & $\begin{array}{l}\text { Scarification by } \\
\text { Hammer }\end{array}$ & 4.27 & 3.46 & 9.19 & 6.97 & 14.96 & 11.77 & 29.01 & 25.23 \\
\hline 66 & $\begin{array}{l}\text { Seed immersed in } \\
\text { cow dung for } \\
\text { overnight }\end{array}$ & 3.55 & 3.16 & 7.70 & 6.06 & 12.76 & 9.87 & 26.67 & 21.97 \\
\hline
\end{tabular}

ANOVA table for Plant height $(\mathrm{cm})$

\begin{tabular}{|c|c|c|c|c|c|c|c|c|}
\hline \multirow{2}{*}{ Factors } & \multicolumn{2}{|c|}{ Two Month } & \multicolumn{2}{c|}{ Four Month } & \multicolumn{2}{c|}{ Six Month } & \multicolumn{2}{c|}{ One Year } \\
\hline & C.D. & SE(m) & C.D. & SE(m) & C.D. & SE(m) & C.D. & SE(m) \\
\hline Factor(A) & 0.14 & 0.05 & 0.09 & 0.03 & 0.14 & 0.05 & 0.18 & 0.06 \\
\hline Factor(B) & 0.25 & 0.08 & 0.17 & 0.05 & 0.25 & 0.08 & 0.31 & 0.10 \\
\hline Factor(A X B) & N/A & 0.12 & N/A & 0.08 & N/A & 0.12 & N/A & 0.15 \\
\hline
\end{tabular}

Thakur and Singh. (2015) recorded the highest percent seed germination (57.26), height $(130.56 \mathrm{~cm})$, girth $(0.57 \mathrm{~cm})$, number of seedlings ready for grafting (46.53) and minimum duration of seed germination (16.33), mortality rate (1.9) in the scarification treatment of Peach.

\section{Survival percent (\%) of saplings}

Table-3 shows the mean values regarding survival percentage. Various seed rupturing methods and nursery sowing method significantly affected survival percentage but the interaction of both factor showed the nonsignificant differences. As for the mean values are concerned for different rupturing methods and nursery sowing method, the seed coat rupturing with hammer had maximum survival percentage for two month, four month, six month and one year after germination of seed i.e. $91.75 \%, 85.00 \%$, $72.75 \%$ and $67.00 \%$ respectively under directly sown seeds in nursery and $90.50 \%$, $80.75 \%, 66.50 \%$ and $58.75 \%$ respectively in nursery sown in polythene bags. In this experiment we observed that during the rainy and summer season sapling mortality rate is 
low and high mortality rate were observed during winter season in all the treatments. The maximum survival percentage were recorded in mechanically ruptured seed coat by hammer might be due to the early germination and healthy plant growth during the initial stage.

\section{Plant height (cm)}

The seed rupturing method and nursery sown method showed gradual differences in plant height (Table-4) but non-significant statistical relationship were recorded for the interaction of both factors. The plant height ranged from $3.3 \mathrm{~cm}$ to $4.27 \mathrm{~cm}, 5.21 \mathrm{~cm}$ to $9.91 \mathrm{~cm}, 9.39$ $\mathrm{cm}$ to $14.96 \mathrm{~cm}$ and $19.99 \mathrm{~cm}$ to $29.01 \mathrm{~cm}$ respectively after two month, four month, six month and one year of germination of seed under direct seeded nursery. While under nursery sown in polythene, the plant height ranged from $2.19 \mathrm{~cm}$ to $3.46 \mathrm{~cm}, 4.02 \mathrm{~cm}$ to $6.97 \mathrm{~cm}, 7.76 \mathrm{~cm}$ to $11.77 \mathrm{~cm}$ and $16.55 \mathrm{~cm}$ to $25.23 \mathrm{~cm}$ respectively, after two month, four month, six month and one year of germination of seed. The maximum plant height under direct seeded and polythene sown nursery were observed in treatment with mechanically rupturing of seed coat by hammer and minimum plant height were recorded in control under both sowing methods. The significant deference's were observed in seed sowing method. Seed sown direct in nursery recorded taller plant as compare to seed sown in polythene bags. The maximum plant growth was recorded during the summer followed by rainy season and slow growth rate were observed during winter season. The maximum plant height were recorded in mechanically ruptured seed coat by hammer might be due to the early germination and healthy plant growth during the initial stage.

\section{Acknowledgement}

The author is thankful to Dr. S. K. Patil, Hon'ble Vice-Chancellor, IGKV, Raipur (C.G.) for providing guideline to conduct this experiment and Programme coordinator, KVK, Dantewada for the moral and material support is provided by them.

\section{References}

Annual report, 2005-06. Centre of Forest Research and Human Resource Development, Chhindwara.

Gomez, K.A. and Gomez A.A. 1984. Statistical Procedures for Agricultural Research (2nd Ed.), John Wiley and Sons, New York, p. 680.

Gopalan, C., Ramashastri, B. V. and Balasubramaniam, S. C. 1982. Report, National Institute of Nutrition, Hyderabad.

Shukla, S.K. and Solanki K.R. 2000. Studies on seed germination, plant survival and growth of chironji (Buchanania lanzan Spreng.) Journal of Tropical Forest 16 (1) 44-49.

Thakur, B. and Singh, H. 2015. Studies on seed germination in peach (Prunus persica L. Batsch) rootstock 'Fordaguard. The Bioscan 10(2): 651654

\section{How to cite this article:}

Kamal Narayan, Deo Shankar, Kedar Nath Yadaw and Narayan Sahu. 2018. Effect of Seed Sowing and Scarification Methods on Germination and Growth of Chironji (Buchnania lanzan Spreng). Int.J.Curr.Microbiol.App.Sci. 7(06): 1291-1296.

doi: https://doi.org/10.20546/ijcmas.2018.706.151 